\title{
PERAN DESAIN BERBANTUAN KOMPUTER (CAD) MAHASISWA JURUSAN DESAIN INTERIOR UNIVERSITAS POTENSI UTAMA
}

\author{
Rizki Hamdani Sitorus \\ Prodi Desain Interior \\ Fakultas Seni dan Desain Universitas Potensi Utama Medan \\ rizki.inst@gmail.com
}

\begin{abstract}
ABSTRAK
Tujuan dari tulisan ini adalah untuk menyelidiki peran desain berbantuan computer (ComputerAided Design (CAD)) dan untuk mengumpulkan informasi umum tentang penggunaan CAD oleh mahasiswa program studi desain interior Universitas Potensi Utama Medan dalam praktik desain interior. Metode penelitian ini adalah metode studi lapangan dan studi literatur. Studi lapangan dilakukan dengan cara memberikan kuesioner ke 50 mahasiswa yang dipilih secara acak pada bulan April 2021. Fokus utama kuesioner adalah pada CAD,metode latihan yang digunakan oleh mahasiswa, dengan pertanyaan yang berkaitan dengan kemampuan CAD dan latar belakang pendidikan mahasiswa. Selain itu, kuesioner menanyakan pertanyaan umum, termasuk jenis CAD yang digunakan, jenis projek yang dilakukan, lama penggunaan CAD, dan metode memperbarui sistem CAD. Sedangkan studi literatur dilakukan dengan cara mencari data-data dari beberapa sumber.
\end{abstract}

Kata kunci : desain berbantuan komputer, desain interior

\begin{abstract}
The purpose of this paper is to describe the role of computer-aided design (CAD) and to gather general information about the use of CAD by students of the interior design study program at Potential Utama University of Medan in interior design practice. This research method is the method of field studies and literature studies. The field study was conducted by giving questionnaires to 50 randomly selected students in April 2021. The main focus of the questionnaire was on $C A D$, the training method used by students, with questions related to CAD abilities and educational background of students. In addition, general questions, CAD used, type of project undertaken, duration of use of CAD, and methods included in the CAD system. While the literature study is done by looking for data from several sources.
\end{abstract}

Keywords: computer-aided design, interior design

\section{PENDAHULUAN}

Computer Aided Design (CAD) pertama kali muncul di perusahaan arsitektur dan desain interior pada tahun 1970-an dan meluas sampai tahun 1980-an (Crosley, 1988). di perusahaan-perusahaan ini CAD digunakan terutama dalam perencanaan Ruang, penyusunan, presentasi, jadwal selesai, jadwal pintu dan jendela, dan gambar dan jadwal kerja lainnya. Dengan fungsi-fungsi ini, CAD dapat sangat membantu dalam mengurangi waktu penyusunan, meningkatkan kualitas gambar, menyatukan penggunaan perpustakaan gambar perusahaan, mengurangi kesalahan, dan membuat komunikasi di perusahaan lebih mudah (Brandon:1987). jumlah yang berkembang pesat dari perusahaan 
arsitektur, desain, dan teknik komputerisasi menunjukkan komputer ada di sini untuk tetap digunakan (Crosley, 1988; Mitchell, 1990).

Saat ini, pendidikan CAD sangat umum di sekolah-sekolah arsitektur dan desain interior, dan siswa yang lulus dengan pelatihan CAD diyakini lebih kompetitif dalam mendapatkan pekerjaan pertama mereka (Fowles, 1987). Di sisi lain, pelatihan CAD untuk para mahasiswa setelah mereka meninggalkan sekolah juga sangat penting. Pengguna komputer baru yang masuk di sekolah desain terkomputerisasi membutuhkan pelatihan awal sementara pengguna yang terampil membutuhkan lanjutan pelatihan untuk mengikuti perangkat lunak baru, upgrade, dan aplikasi yang lebih canggih. Fakultas yang mengajar CAD di perguruan tinggi, universitas, dan sekolah teknik juga menghadapi masalah melanjutkan pendidikan di CAD. Ada sangat sedikit penelitian yang dilakukan pada pelatihan dan pendidikan berkelanjutan penggunaan $\mathrm{CAD}$ oleh profesional dan instruktur CAD.

Tujuan dari penelitian ini adalah untuk menyelidiki peran CAD terhadap para mahasiswa desain interior dan untuk mengumpulkan informasi umum tentang penggunaan $\mathrm{CAD}$ oleh mahasiswa.Tujuan utama dari penelitian ini adalah:

1. Untuk menentukan peranan $\mathrm{CAD}$ yang digunakan oleh mahasiswa desain interior dan

2. Untuk mengidentifikasi sejauh mana penggunaan komputer membantu mahasiswa desain interior

\section{STUDI LITERATUR}

Sistem CAD generasi pertama digerakkan oleh komputer mainframe. Mereka membutuhkan ruangan dengan pendingin udara khusus, membutuhkan operator khusus, dan terlalu besar untuk masuk ke dalam studio desain. Generasi kedua (awal 1970-an) sistem CAD didorong oleh komputer mini 16-bit dan biasanya memiliki tabung penyimpanan untuk display (Mitchell, 1990). Pada akhir 1970-an, hanya perusahaan desain dan rekayasa yang besar yang mampu membeli sistem drafting dua dimensi yang menelan biaya ratusan ribu dolar. Paket perangkat lunak sulit dipelajari untuk digunakan. Perusahaan sering kali harus menjaga drafter bekerja dua atau tiga shift sehari untuk mendapatkan keuntungan (Crosley, 1988).

Dengan kemajuan perangkat keras dan perangkat lunak komputer sejak tahun 1980an, komputer telah menjadi terjangkau bahkan untuk perusahaan yang agak kecil. Jumlah publikasi dan bentuk informasi lainnya yang signifikan sekarang tersedia untuk pengguna komputer. CAD telah diadaptasi oleh orang-orang di bidang arsitektur, desain, teknik, dan desain industri (Mitchell, 1990; Crosley, 1988).

Desainer interior telah mengadopsi komputer ke dalam lingkungan kantor sedikit lebih lama dari profesi lainnya. Salah satu alasannya mungkin karena kurangnya komunikasi antara desainer dan pemrogram perangkat lunak. Jika pemrogram perangkat lunak tidak memahami proses desain dengan sangat baik, mereka tidak bisa menghasilkan perangkat lunak yang memadai untuk pengguna di lapangan (Brandon, 1987).

Biaya sistem CAD dan rasa takut bekerja di komputer alih-alih menggambar dengan alat yang sudah dikenal adalah alasan tambahan mengapa CAD memakan waktu yang lama untuk masuk ke perusahaan desain interior. Beberapa desainer merasa bahwa komputer mengurangi kreativitas mereka (Gladstone, 1985). Ketika komputer menjadi lebih populer dan lebih mudah dioperasikan, orang-orang secara bertahap menyadari bahwa mereka memiliki hubungan yang dominan dengan komputer. Di artikelnya With Machines Doing the Thinking, What's Left for Designers?, Garant (1983) menunjukkan, 
"Harus diingat bahwa dalam hubungan manusia/mesin, manusia adalah penyebab dan orang yang membuat pilihan akhir" (hal. 104).

Pada akhir 1980-an penggunaan CAD di profesi desain interior menjadi luas. Di sebuah survei dari 500 American Society of Interior Designers (ASID) anggota dilakukan pada tahun 1985 oleh McLain-Kark dan Tang (1986), hanya 7\% yang menggunakan CAD. Namun, pada tahun-tahun berikutnya, jumlah perusahaan yang menggunakan CAD meningkat secara dramatis. Menurut sebuah laporan di Interior Desain, 84\% dari 100 perusahaan desain interior teratas di seluruh negara tersebut menggunakan sistem CAD internal pada tahun 1988 (Loebelson, 1989a). Penggunaan CAD di 100 raksasa desain interior meningkat dari 49\% pada tahun 1986 menjadi 92\% pada tahun 1989 (Loebelson, 1989b). Namun; antara perusahaan kecil dan perusahaan perumahan masih ada hanya sedikit sedikit yang telah mengadopsi sistem CAD. Pada akhir 1980-an, karena sistem CAD memperoleh penerimaan yang luas dan cepat, vendor siap untuk menempatkan upaya yang signifikan ke dalam mendiskusikan kebutuhan klien tertentu dan menyesuaikan sistem. Mereka biasanya memberikan pelatihan pengguna yang ekstensif dan dukungan untuk setiap instalasi (Mitchell, 1990).

Dalam sebuah studi tahun 1989 oleh Clemons dan McCullough, 85\% dari responden setuju bahwa siswa harus dilatih pada CAD selama pendidikan sekolah desain perguruan tinggi mereka. Dua pertiga merasa lulusan desain dengan pelatihan CAD memiliki keunggulan yang pasti dibandingkan lulusan desain lainnya mencari posisi pekerjaan pertama mereka. Pada tahun 1987 survei nasional tentang sikap desainer interior menuju pendidikan berkelanjutan, 63\% dari 878 desainer yang menyelesaikan kuesioner tertarik pada aplikasi komputer dalam praktik desain dan $60 \%$ adalah tertarik pada desain dan penyusunan berbantuan komputer (Fowles, 1987).

Pada pertengahan 1980-an, gelombang komputer dalam pendidikan desain melanda sekolah desain interior. Pada tahun 1990, Clemons dan McLain-Kark mengirimkan survei di CAD pendidikan ke IDEC yang dipilih secara acak (dewan pendidik Desain Interior) anggota di seluruh Amerika Serikat. Delapan puluh sembilan persen dari desain interior yang merespons sekolah telah memasukkan pendidikan CAD di berbagai tingkat kurikulum mereka.

Pada tahap awal pengembangan CAD, perangkat lunak paket tidak secanggih sekarang dan tidak ada paket yang dirancang khusus untuk arsitek dan desainer. Banyak perusahaan harus menyesuaikan CAD perangkat lunak yang sesuai dengan praktik mereka sendiri. Sekarang, ada banyak paket perangkat lunak CAD tersedia yang telah ditingkatkan selama bertahun-tahun dan memiliki kemampuan yang sangat baik dalam desain dan perancangan arsitektur. Ada juga paket perangkat lunak yang dirancang khusus untuk arsitek dan desainer. Meskipun sebagian besar desain dan pekerjaan penyusunan dapat dilakukan tanpa menyesuaikan paket perangkat lunak, perusahaan dapat menemukan peningkatan efisiensi ketika perangkat lunak telah disesuaikan untuk memenuhi kebutuhan mereka (Kennedy, 1986). Menyesuaikan mungkin termasuk: menulis makro, menambah menu yang ada, menambahkan fungsi atau perintah penyusunan atau perhitungan baru, atau menambahkan subrutin ke sistem (Smith \& Gesner, 1988).

Beberapa perangkat lunak CAD yang bersifat "terbuka", yang memungkinkan pengguna untuk menyesuaikan atau menambah program, sementara perangkat lunak lain "ditutup" dan tidak memungkinkan modifikasi. Perangkat lunak yang terbuka memiliki bahasa pemrograman pengguna seperti: Autolisp AutoCAD (Crosley, 1988). Ada juga pasar yang dikembangkan untuk perusahaan arsitektur dan desain untuk membeli dan menjual program tambahan mereka, yang dapat menghemat banyak waktu untuk pekerjaan yang berulang-ulang (Crosley, 1988). 
Oleh karena itu, dengan meningkatnya penggunaan komputer di bidang desain, ada kebutuhan untuk lebih memahami peranan CAD untuk mahasiswa. Mahasiswa mungkin memiliki sejumlah pengalaman dan minat untuk terampil dalam penggunaan CAD. Penelitian ini akan mencoba untuk mengungkapkan peran penting CAD.

\section{PEMBAHASAN}

Tujuan utama dari penelitian ini adalah untuk menyelidiki peran CAD dan penggunaan $\mathrm{CAD}$ oleh mahasiswa desain interior. Untuk mendapatkan tujuan ini, kuesioner diberikan kepada beberapa mahasiswa. Kuesioner diberikan pada bulan April 2021.Untuk mencapai persentase pengguna CAD yang tinggi, sampel termasuk 50 mahasiswa yang dipilih secara acak dari program studi desain interior. Mahasiswa ini dipilih karena ada keterlibatan CAD dalam proses belajar mereka. Kuesioner mencakup lima belas pertanyaan tertutup yang dirancang untuk menilai metode yang digunakan mahasiswa dalam menggunakan aplikasi CAD.

Saat menyelesaikan survei, para desainer ditanya untuk "memeriksa semua jawaban yang sesuai." Untuk sebagian besar pertanyaan, responden memeriksa lebih dari satu jawaban, sehingga persentase total tanggapan untuk pertanyaan-pertanyaan ini dapat menjadi lebih besar dari $100 \%$. Persentase total menunjukkan rasio antara total jawaban yang diperiksa untuk sebuah pertanyaan dan jumlah orang yang menjawab pertanyaan. Temuan disajikan dalam dua kategori:

1. Metode latihan CAD dan

2. Penggunaan CAD dalam projek mahasiswa.

Kuesioner dirancang untuk mengeksplorasi pelatihan metode dua kelompok mahasiswa: mereka yang terpilih sebagai "pengguna pertama" adalah mereka yang pernah mengikuti pelatihan atau kursus CAD sebelum masuk perguruan tinggi dan mereka yang dilatih di perguruan tinggi di kemudian hari sebagai "pengguna kedua". Selain itu, informasi dicari untuk menentukan apakah pelatihan yang sebenarnya memiliki metode berbeda dari metode pelatihan yang disukai. Tabel 1 merangkum metode pelatihan untuk keduanya kelompok pengguna CAD.

\section{Tabel 1 : Metode Pelatihan Bagi Responden}

\begin{tabular}{|l|l|l|l|}
\hline Metode Pelatihan & Pengguna pertama & Pengguna kedua & Menyukai Metode \\
\hline & $\mathrm{n}=39$ & $\mathrm{n}=11$ & $\mathrm{n}=50$ \\
\hline Pelatihan untuk dunia kerja & $45 \%$ & $30 \%$ & $76 \%$ \\
\hline Pelatihan dengan manual aplikasi & $32 \%$ & $9 \%$ & $8 \%$ \\
\hline Kursus CAD & $6 \%$ & $0 \%$ & $24 \%$ \\
\hline Pelatihan dengan magang tempat kerja & $65 \%$ & $70 \%$ & $82 \%$ \\
\hline Pelatihan Mandiri & $44 \%$ & $55 \%$ & $68 \%$ \\
\hline Jawaban boleh lebih dari satu & & & \\
\hline
\end{tabular}

Dari 50 responden (100\% dari sampel), $78 \%$ menunjukkan bahwa mereka sebagai pengguna pertama yang telah menerima pelatihan CAD sebelum perguruan tinggi dan sisanya $22 \%$ sebagai pengguna kedua yang menerima pelatihan CAD setelah masuk perguruan tinggi. Sebanyak $45 \%$ dari pengguna pertama pernah mengikuti pelatihan untuk dunia kerja, 32\% mengikuti pelatihan dengan manual aplikasi, 6\% melalui kursus CAD, $65 \%$ mengikuti pelatihan di tempat magang dan $44 \%$ melakukan pelatihan mandiri.

Sedangkan dari pengguna kedua $30 \%$ pernah mengikuti pelatihan untuk dunia kerja, 9\% mengikuti pelatihan dengan manual aplikasi, 0\% melalui kursus CAD, 70\% mengikuti pelatihan di tempat magang dan 55\% melakukan pelatihan mandiri. Dan 
berdasarkan metode-metode tersebut $76 \%$ menyukai metode pelatihan untuk dunia kerja, $8 \%$ menyukai pelatihan dengan manual aplikasi, 24\% menyukai curses CAD, $82 \%$ menyukai pelatihan di tempat magang dan $68 \%$ menyukai pelatihan mandiri.

Hasil mengenai metode pelatihan mahasiswa mengungkapkan beberapa fakta menarik. Banyak (82\%) dari mahasiswa menyukai metode pelatihan dengan magang di tempat kerja, hal ini dapat menjadi poin yang perlu diperhatikan oleh sekolah dan perguruan tinggi desain dalam memenuhi kebutuhan mahasiswa tersebut.

Salah satu pertanyaan survei berusaha untuk menentukan apakah metode yang mereka gunakan untuk menggunakan CAD berbeda dari metode yang dianggap ideal oleh professional dan apakah pihak universitas mengkompromikan yang terbaik untuk situasi pelatihan karena kendala uang, waktu, atau lokasi. Tampaknya tidak ada perbedaan besar dalam metode yang sebenarnya dan yang disukai dalam metode penggunaan CAD. Salah satu hasil yang mengejutkan adalah 31\% mengatakan mereka lebih suka "belajar sendiri" dengan cara manual. Penggunaan manual lebih murah. Namun, seseorang harus mempertanyakan keefektifan metode yang digunakan. Sebuah studi lanjutan yang menilai efektivitas berbagai metode pelatihan bisa lebih baik menunjukkan metode apa yang sebenarnya seharusnya direkomendasikan.

Ketika ditanya paket perangkat lunak mana yang dipilih oleh mahasiswa, Autodesk adalah perangkat lunak yang paling umum digunakan (73\%). Informasi ini dapat membantu untuk perusahaan desain dan lembaga pendidikan dihadapkan dengan keputusan pemilihan perangkat lunak. Meskipun banyak paket perangkat lunak yang sangat baik tersedia dan desainer dan siswa dapat beralih dari satu paket ke lain tanpa terlalu banyak kesulitan, mengetahui apa sedang digunakan dalam industri dapat membuat pilihan atau proses transisi lebih mudah.

Banyak program desain interior mengeksplorasi perangkat lunak pilihan yang mereka rasa memungkinkan siswa untuk mendesain dengan bebas karena mereka percaya komitmen utama mereka adalah untuk mengembangkan desainer yang baik. Beberapa menggunakan berbagai paket perangkat lunak dan platform sehingga siswa dapat merasakan antarmuka yang nyaman dengan berbagai paket. Pendidik harus mengingatkan siswa bahwa mereka akan mengalami berbagai situasi CAD saat berburu pekerjaan, termasuk berbagai perangkat keras, perangkat lunak, dan sistem operasi. Siswa tidak boleh meragukan kemampuan mereka untuk

mempelajari paket perangkat lunak karena interface mungkin terlihat sedikit berbeda dari yang pernah mereka kerjakan sebelumnya.

Sebagian besar pekerjaan desain yang dilakukan di komputer adalah pekerjaan dua dimensi dengan denah lantai, elevasi, dan gambar konstruksi lainnya. Ini temuan konsisten dengan penelitian sebelumnya tentang penggunaan CAD. Namun, jumlah responden yang mengejutkan dilaporkan bekerja dengan CAD untuk gambar rangka $(66 \%)$ dan rendering (88\%). Temuan ini menunjukkan bahwa persentase yang cukup besar mahasiswa melaukan pekerjaan 2 dimensi dan 3 dimensi dengan bantuan CAD. Selain itu, pendidik sering dihadapkan pada keputusan seberapa jauh Kurikulum CAD harus membawa siswa sebelum mereka lulus. Apakah kursus 2D awal cukup atau harus siswa menjadi kompeten dalam 3D juga? Melihat ini, pendidik mungkin ingin mempertimbangkan untuk memasukkan CAD 3D ke dalam kurikulum mereka jika mereka belum melakukannya.

Untuk mendapatkan gambaran tentang penggunaan CAD dalam projek mereka, responden ditanya bagian apa dari projek mereka yang diselesaikan dengan CAD. $92 \%$ menunjukkan bahwa mereka menggunakan CAD untuk mengerjakan denah, 74\% menggunakan $\mathrm{CAD}$ untuk mengerjakan elevasi, 66\% telah menyelesaikan gambar konstruksi, 52\% pengguna membuat gambar rangka dan permodelan $3 \mathrm{D}, 42 \%$ 
menggunakan CAD untuk mengelola fasilitas, dan $88 \%$ melakukan rendering pada CAD.

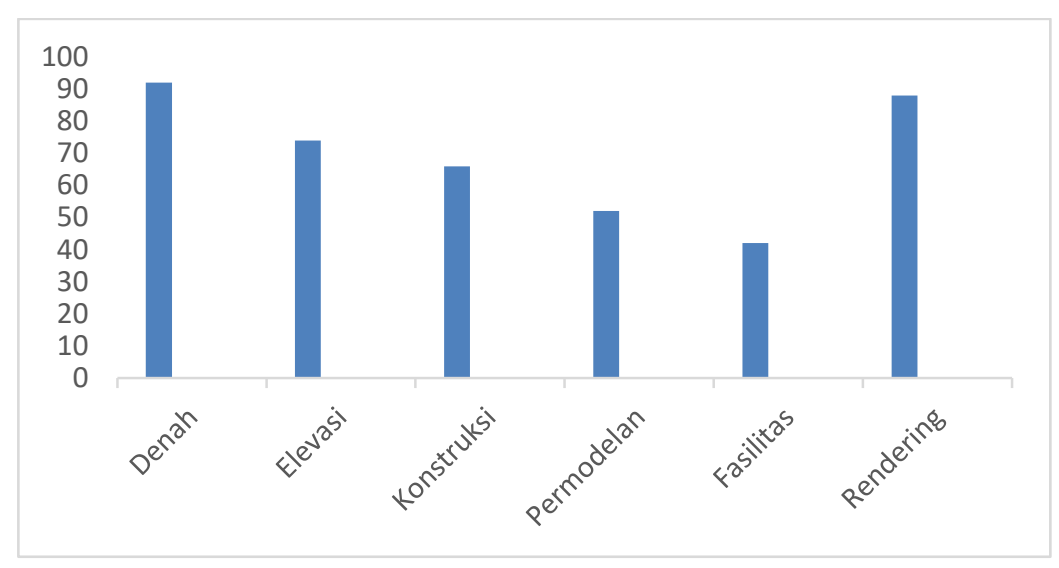

Chart 1 : Bagian Projek yang Diselesaikan dengan CAD

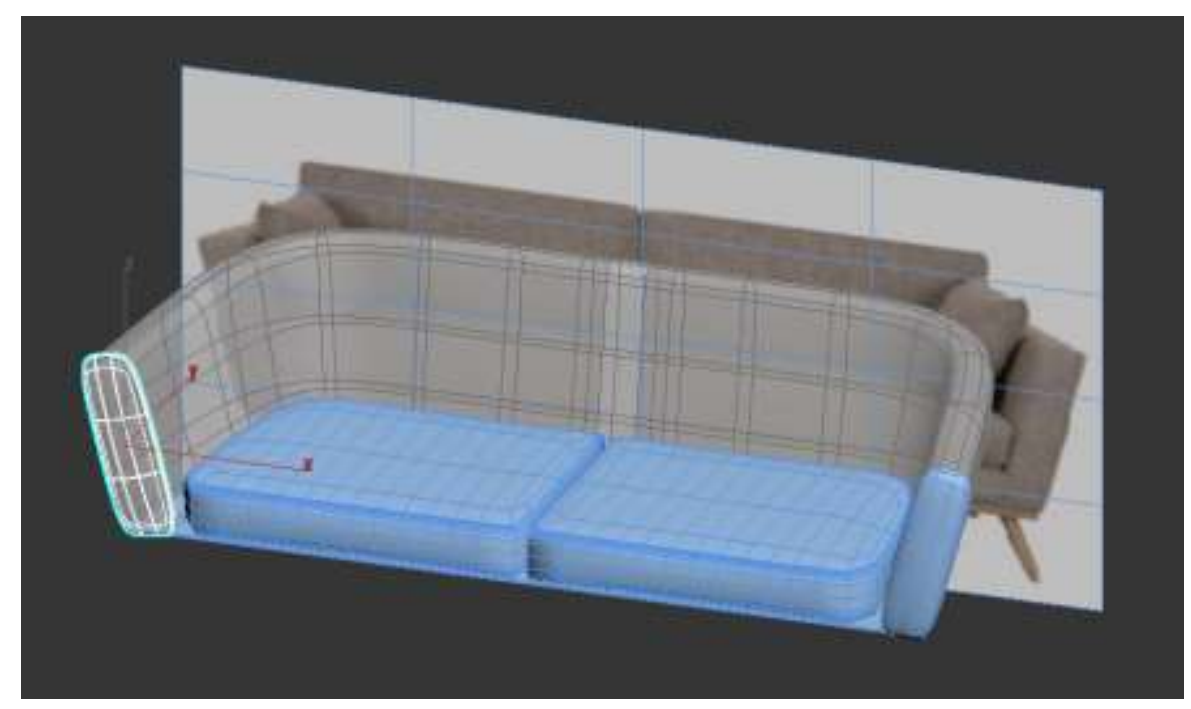

Gambar 1 : Penggunaan aplikasi CAD dalam permodelan

Dengan adanya keterlibatan CAD di dalam beberapa kegiatan projek mahasiswa, kemungkinan adanya penyesuaian aplikasi CAD yang dilakukan untuk memaksimalkan aplikasi CAD agar dapat memenuhi kebutuhan mereka. 28\% mahasiswa melakukan penyesuaian pada aplikasi CAD dan $72 \%$ tidak melakukan penyesuaian.

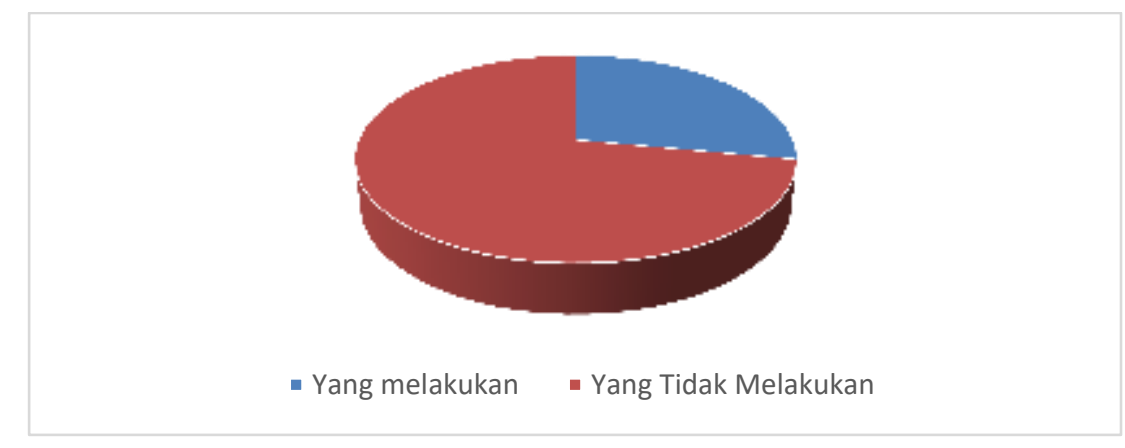

Chart 2 : Mahasiswa yang melakukan penyesuaian aplikasi CAD 
Sebagian kecil mahasiswa menyesuaikan perangkat lunak mereka (28\%). Ini biasanya berarti bahwa perangkat lunak tidak memenuhi kebutuhan mahasiswa. Ada mahasiswa yang melakukan modifikasi karena latar belakang komputer. Ini memberi keuntungan lebih bagi mereka dimana hasil desain dengan tambahan modifikasi lebih bagus. Namun adanya modifikasi pada aplikasi CAD maka dibutuhkan spesifikasi yang lebih, pengetahuan tambahan tentang modifikasi yang dilakukan, waktu pengerjaan yang lebih lama dan lebih detail serta waktu rendering hasil kerja yang lebih lama.

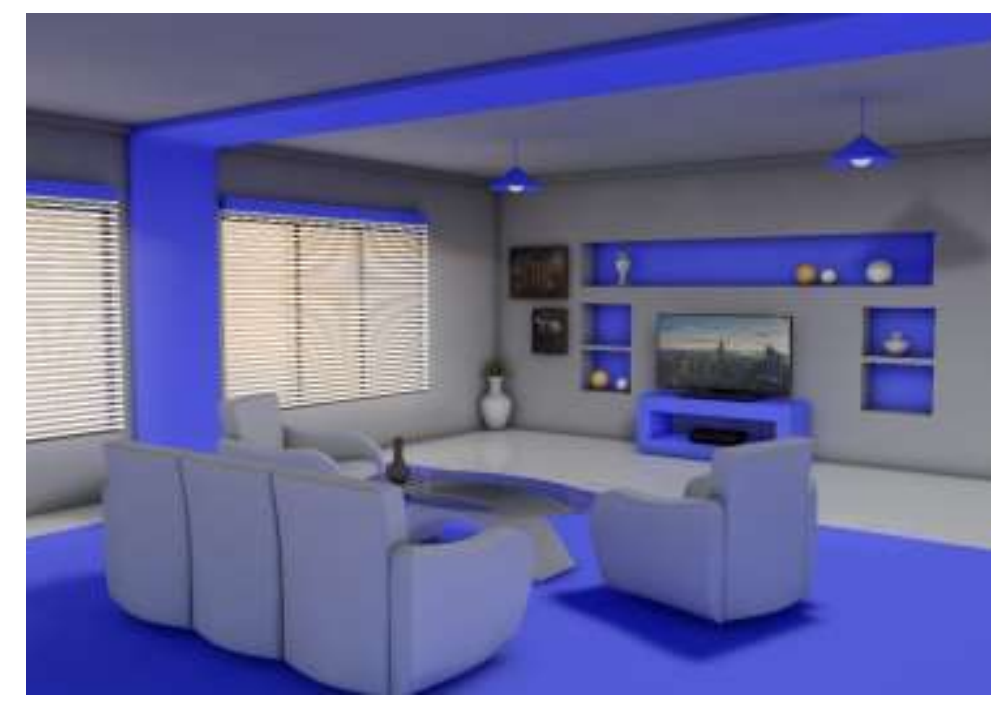

Gambar 2 : Hasil render tanpa modifikasi tambahan pada aplikasi CAD

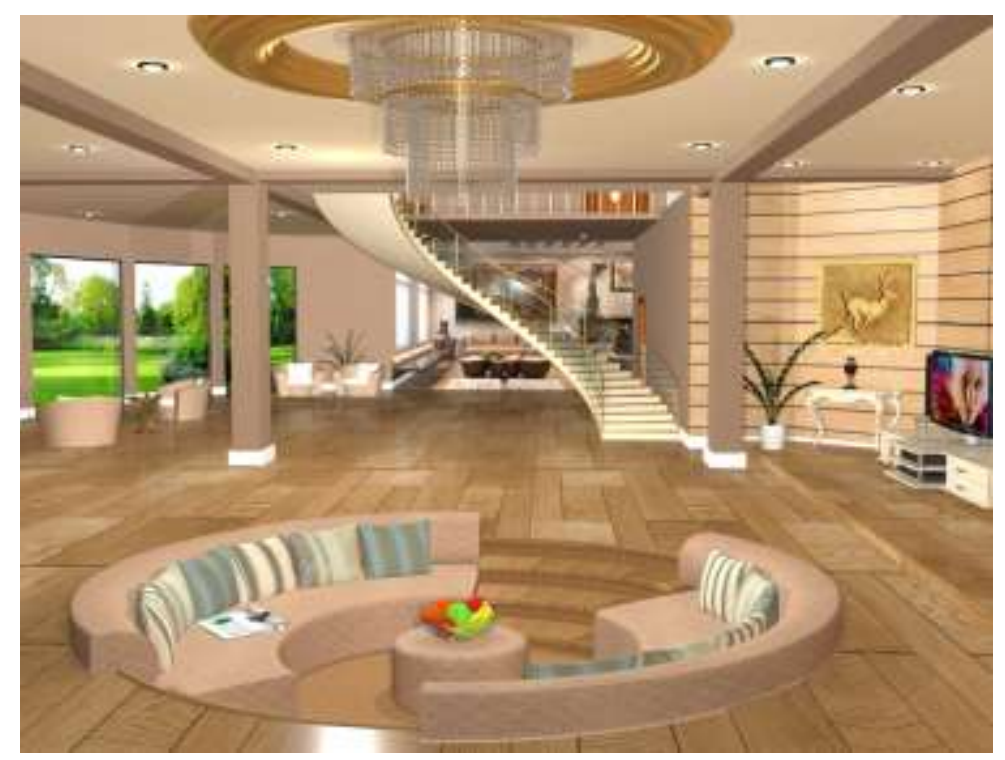

Gambar 3 : Hasil render dengan modifikasi tambahan pada aplikasi CAD

Lalu 54\% dari mahasiswa yang melakukan penyesuaian berdasarkan pengetahuan dari pelajaran desain dan $46 \%$ melakukan penyesuaian berdasarkan pengetahuan dari pelajaran komputer. Ada 54\% mahasiswa yang mendapatkan pengetahuan dalam penyesuaian aplikasi CAD dari pelajaran desain dan $46 \%$ dari pelajaran computer ini membuktikan pelajaran computer dan desain yang berhubungan dengan $\mathrm{CAD}$ memberikan pengaruh yang besar. Hanya sebagian kecil mahasiswa yang melakukan pembaruan perangkat lunak mereka (22\%) setiap tahun. Ini berarti bahwa ada kemungkinan mahasiswa tidak memenuhi persyaratan didunia profesional. 
Sehingga mahasiswa tersebut harus melatih dirinya dengan aplikasi yang baru.

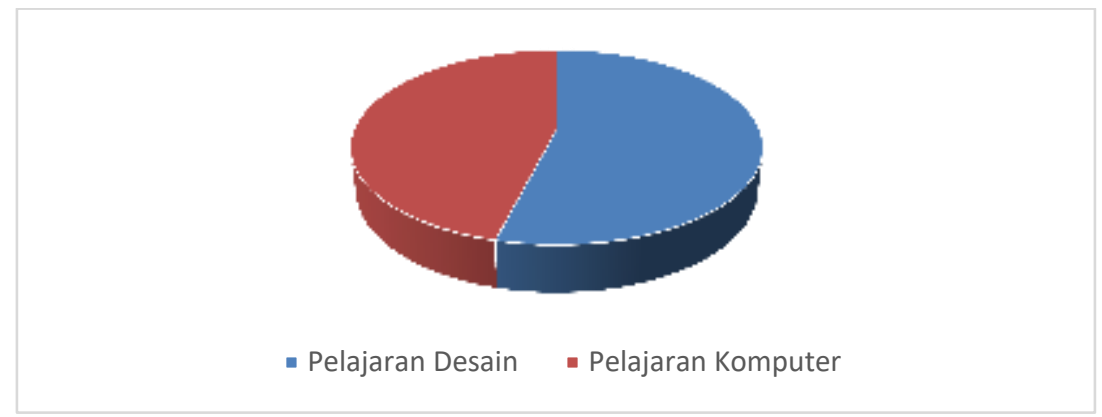

Chart 3 : Sumber pengetahuan penyesuaian aplikasi CAD

Dari data yang ditampilkan di situs web Autodesk, sebagai salah satu produsen aplikasi CAD yang paling banyak digunakan saat ini menunjukkan bahwa pada salah satu aplikasinya yaitu 3DS MAX mulai dari tahun 2014 selalu melakukan pembaruan terhadap aplikasi dan system yang dibutuhkan. Adanya pembaruan pada sebuah aplkasi CAD maka besar kemungkinan pembaruan juga dilakukan pada aplikasi yang sejalan ataupun pihak ketiga yang terhubung dengannya

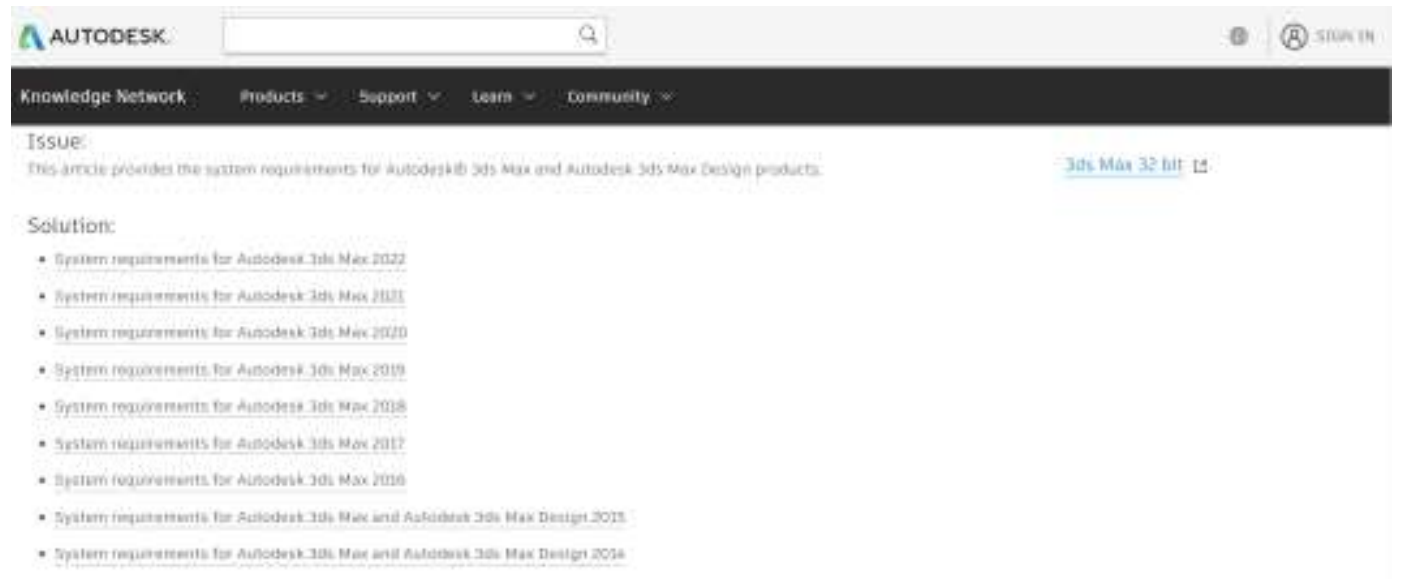

Gambar 4 : Pembaruan kebutuhan system pada aplikasi 3DS max

Dengan teknologi yang terus berubah, mahasiswa mungkin membutuhkan memperbarui perangkat keras dan/atau perangkat lunak secara berkala. Namun memperbarui perangkat lunak dapat mengganggu ketika waktu yang dihabiskan untuk memuat perangkat lunak atau membuat pembaruan dalam perangkat keras. Untuk memberikan wawasan tentang frekuensi pemutakhiran, masalah yang mungkin timbul saat pemutakhiran, dan kebutuhan pelatihan terkait, responden ditanya seberapa sering mereka memperbarui atau memperluas sistem mereka. $22 \%$ pengguna memiliki sistem mereka diperbarui setiap tahun, 34\% diperbarui atau diperluas setiap 1-2 tahun, dan 44\% diperluas setiap 3-5 tahun. 


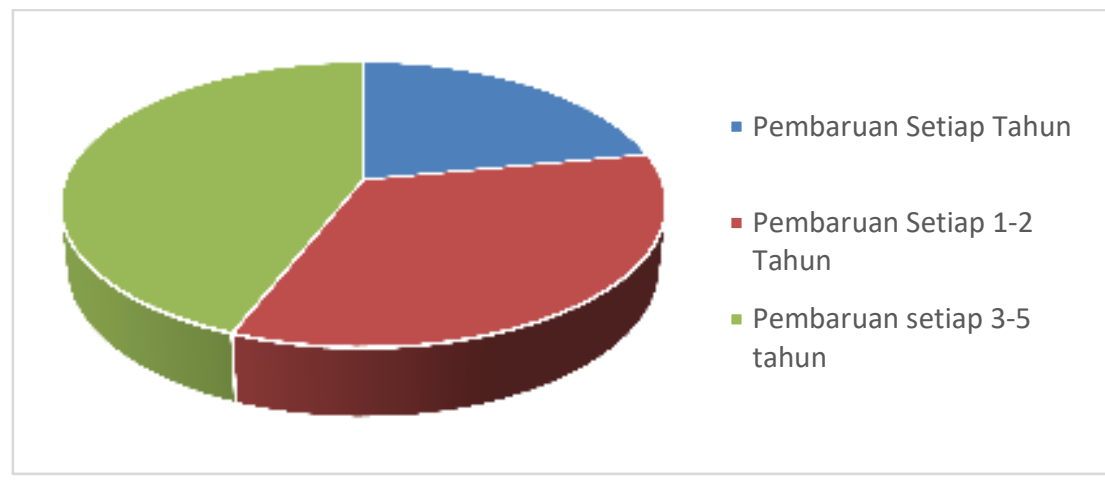

Chart 4 : Rentang waktu pembaruan system CAD

\section{KESIMPULAN}

Hasil penelitian ini memberikan wawasan tentang penggunaan CAD dan jalan potensial yang tersedia untuk melatih mahasiswa desain tentang CAD. Selain itu, pendidik dan siswa dapat lebih memahami tantangan menggabungkan CAD ke dalam lingkungan kerja dan lebih siap untuk tantangan itu.

Survei tersebut berfokus pada dua kelompok responden : mereka dilatih terlebih dahulu (pengguna CAD pertama) dan mereka yang dilatih di kemudian hari (pengguna CAD kedua). Peran pelatihan sangat penting baik untuk pengguna pertama dan pengguna kedua. Oleh karena itu, mahasiswa harus menyadari ketersediaan pelatihan dan mencarinya. Para responden ini mungkin dapat berbicara dengan responden lainnya untuk melihat seberapa puas mereka dengan pelatihan yang telah mereka lalui.

Pendidik mungkin dapat menghubungi perusahaan perangkat keras dan perangkat lunak untuk mengetahui apakah mereka memiliki dukungan jasa dalam pendidikan. Banyak perusahaan perangkat lunak memiliki program pendidikan, buletin, dan lokakarya untuk pendidik. Baik praktisi maupun pendidik dapat memperoleh manfaat dari lokakarya di konferensi dan pameran dagang. Kebanyakan ini diajarkan oleh orang-orang dengan pengetahuan menyeluruh tentang produk $\mathrm{CAD}$.

Ketika ditanya bagaimana peran pengguna utama bagi pengguna kedua, $68 \%$ mengatakan bahwa pengguna pertama berperan penting dalam proses pembelajaran mereka. Oleh karena itu, tampaknya ada menjadi keuntungan untuk memberikan projek bersama yang melibatkan kedua pengguna. Tetapi aka nada potensi hilangnya produktivitas pengguna pertama ini saat mereka membantu orang lain, pendidik harus mengeksplorasi potensi keuntungan dan kerugian dari opsi ini.

Perguruan tinggi dan universitas lokal, serta komunitas perguruan tinggi dan sekolah teknik, dapat menjadi sumber yang baik untuk mahasiswa yang mencari pelatihan untuk belajar CAD. Pilihan kelas mungkin fomal atau nonformal, Pendidik dan praktisi mempelajari keterampilan dasar CAD sering mendapat manfaat dari kelas yang tersebar setidaknya selama beberapa minggu sehingga keterampilan dapat diperkuat. Kelas singkat dua atau tiga hari sangat membantu untuk mendapat ikhtisar tentang apa yang ditawarkan perangkat lunak, tetapi apakah itu ideal untuk pemula yang perlu menyerap dalam jumlah besar dari informasi.

Penting untuk mengenali peran saat ini yang dimainkan oleh pendidikan desain interior dalam pelatihan CAD. Dalam sebuah survei anggota Dewan Pendidik Desain Interior (IDEC) oleh Clemons dan McLain-Kark (1990), 89\% dari menanggapi sekolah desain interior telah dimasukkan $\mathrm{CAD}$ ke dalam kurikulum mereka. Dengan persentase 
yang besar (44\%) perusahaan desain mempekerjakan desainer dengan yang sudah ada Keterampilan CAD untuk membantu perusahaan melakukan transisi ke CAD dan dengan 53\% karyawan yang mahir CAD terlibat dalam pelatihan desainer lain, siswa lulus dengan keterampilan ini tampaknya memiliki keuntungan yang pasti.

Meskipun keterampilan awal harus diperoleh untuk menggunakan CAD, perubahan perangkat lunak dan perangkat keras yang sering membutuhkan mahasiswa untuk tetap mengikuti perkembangan baru. Dari hal itu mahasiswa yang telah melalui pelatihan komputer, mereka dapat memperbarui tanpa terlalu banyak bantuan dari sumber lain. Oleh karena itu, perusahaan desain harus yakin bahwa begitu desainer mendapatkan pelatihan, mereka akan dapat mempertahankan keterampilan mereka tanpa terlalu banyak waktu atau uang yang dihabiskan untuk tambahan latihan. Ini bisa meringankan beberapa kecemasan yang disebabkan dengan teknologi yang berkembang pesat yang membutuhkan peningkatan perangkat keras, perangkat lunak, dan pengetahuan. Perguruan tinggi dan sekolah desain juga harus menghargai pentingnya pembaruan pembelajaran, perangkat lunak baru atau perubahan sering kali memerlukan bantuan dari luar dan waktu untuk itu.

\section{DAFTAR PUSTAKA}

[1]. Brandon, 1. (1 987). Penggunaan Komputer dalam Praktik Profesional Desain Interior: Aplikasi untuk Pendidikan Desain Interior. Tesis master tidak diterbitkan, The Universiiy of Alabama, Tusca loosa .

[2]. Clemons, S., \& McCullough, J. (1 989). Sikap desainer interior terhadap pendidikan CADD dan CADD. Jurnal Pendidikan dan Penelitian Desain Interior,15(2), 29-34.

[3]. Clemons, S., \& Mclain-Kark, J. (1 990). Desain berbantuan komputer dalam program desain interior: Status dan tantangan. Jurnal Pendidikan dan Penelitian Desain Interior, 17(2), 47-50.

[4]. Crosley, M. (1 988). Panduan arsitek untuk desain berbantuan komputer. New York: John Wiley \& Sons.

[5]. Fowles, D. (1 987). Studi pendidikan berkelanjutan desain interior: Sikap profesi. Jurnal Pendidikan dan Penelitian Desain Interior,13(2), 3-1 8.

[6]. Garant, C. (1 983). Dengan mesin yang berpikir, apa yang tersisa untuk desainer? Design Condon), 4 19, 104.

[7]. Gladstone, D. (1 985, September). Mendesain dengan CAD. Desain interior,56(9), 3 12-3 15.

[8]. Https://knowledge.autodesk.com/support/3dsmax/troubleshooting/caas/sfdcarticl es/sfdcarticles/System-requirements-for-Autodesk-3ds-Max-products.html

[9]. Kennedy, E. (1 986). CAD: Desain, penyusunan, manajemen data. New York Whitney Library of Design. 
[10]. Loebelson, A. (1 9890, January).100 raksasa desain interior. Desain interior, 60(1), 141-154.

[11]. Loebelson, A. (1989b, July).

[12]. 100 raksasa desain interior kedua tahun 1989. Inferior Design, 60( lo), 1 17-1 19.

[13]. Mclain-Kark, J., \& Tang, R. (1 986). Penggunaan komputer dan sikap terhadap komputer di bidang desain interior. Jurnal Pendidikan dan Penelitian Desain Interior, 12(2), 25-32.

[14]. Mitchell, W. (1 990). Studio desain elektronik: Pendidikan arsitektur di era komputer. Cambridge, MA: MIT Press.

[15]. Smith, J., \& Gesner, R. (1 988). Customizing AutoCAD Customizing AutoCAD. Thousand Oaks, CA New Riders Publishing.

[16]. Wagner, W. (1 985, June). Bagaimana nasib perusahaan dengan komputer dan apa yang ditunggu oleh non-pengguna? Catatan Arsitektur, 173(7), 37-41 